\title{
Artelogie
}

Recherche sur les arts, le patrimoine et la littérature de l'Amérique latine

9| 2016

Horizons et perspectives de la culture en Colombie (1990-2015)

\section{Erotismo y transgresión en la obra "El delirio de las monjas muertas" de Juan Antonio Roda}

Aline Miklos

\section{OpenEdition}

\section{Journals}

Edición electrónica

URL: http://journals.openedition.org/artelogie/725

DOI: $10.4000 /$ artelogie. 725

ISSN: 2115-6395

Editor

Association ESCAL

Referencia electrónica

Aline Miklos, "Erotismo y transgresión en la obra "El delirio de las monjas muertas" de Juan Antonio Roda », Artelogie [En línea], 9 | 2016, Publicado el 20 junio 2016, consultado el 18 noviembre 2020

URL : http://journals.openedition.org/artelogie/725 ; DOI : https://doi.org/10.4000/artelogie.725

Este documento fue generado automáticamente el 18 noviembre 2020

Association ESCAL 


\section{Erotismo y transgresión en la obra "El delirio de las monjas muertas" de Juan Antonio Roda}

Aline Miklos

\section{Introducción}

"El delirio de las monjas muertas" (1972-1974), de Juan Antonio Roda ${ }^{1}$ (Valencia, España, 1921 Bogotá, Colombia, 2003), fue considerada por muchos críticos como la obra de mayor aliento emprendida por el artista ${ }^{2}$. Adriana Navarro

Juan Antonio Roda, "El delirio de las monjas muertas", 1972-74

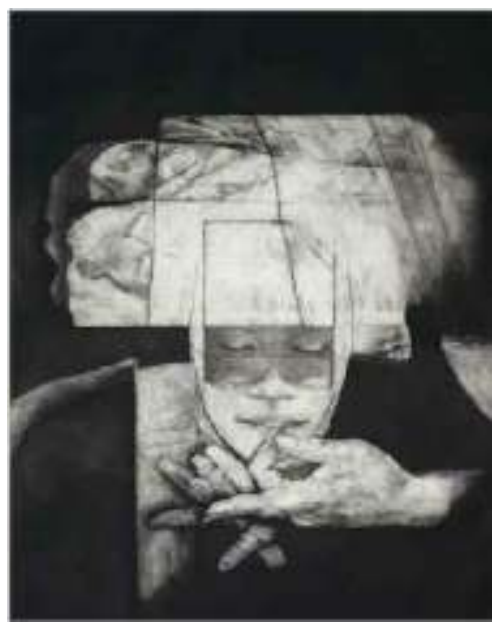

aguafuerte, aguatinta y puntaseca, 49x64 cm. Fuente : http://www.juanantonioroda.com 
1 En este artículo, las 12 imágenes que componen la serie de grabados son analizadas a partir de tres paradojas principales: la de las palabras, la de las imágenes y la de los tiempos.

2 En cuanto a la primera, propuesta por el título, cabe preguntarse cómo es el delirio de las monjas muertas. ¿Las monjas muertas pueden delirar? ¿Cómo es el delirio de las monjas sobre la muerte? ¿Por qué delirio y muerte? Así, se observa que el título posee en realidad un grupo de palabras con significados yuxtapuestos que necesitan ser desmembrados para entenderlos.

3 La segunda paradoja, la de las imágenes, no es menos intrigante que la primera, pues por detrás de penachos, dedos, falos, ojos, manos y velos, existe un juego metafórico en el cual los sentidos originarios de estos referentes son transgredidos. De este modo se forman nuevas cadenas de significados.

4 La tercera paradoja está basada en la superposición de los tiempos (pasado, presente y futuro), que pueden ser entendidos en dos dimensiones. Por un lado, el tiempo individual, o el que cabe en la vida de una monja; por otro, el tiempo histórico, que relaciona la obra y su contenido a toda una tradición católica y occidental.

5 En cuanto al primero, aquí se demuestra de qué manera en la obra de Roda las experiencias místicas vividas por las monjas se mezclan y se deslizan una hacia la otra. Así, se observa que no existen fronteras determinadas entre éxtasis, fantasías, visiones, delirios y muerte. Además, tampoco existe una línea divisoria entre pasado y presente en las experiencias místicas narradas por el artista. Al llamarlas "delirio", Roda considera que hay una mezcla inevitable y confusa entre estos dos tiempos en la vida de las monjas, pues este es el principio de la formación delirante.

6 En cuanto al tiempo histórico, aparece a través de las múltiples referencias externas encontradas en la obra que en este artículo se denominan "espectros”. Según Jacques Derrida, estos espectros perturban la cronología, ultrapasan la línea del presente, desincronizan y nos remiten a la anacronía. Todo esto se da porque el espectro no se encuadra en ninguna filosofía del sujeto, es un no objeto, un no lugar, ni presente ni ausente y que no se sabe si está vivo o muerto (DERRIDA, 1998: 20).

7 Los espectros permiten al espectador ir y volver en el tiempo. Ir a lugares y tiempos que, aunque dan la simple impresión de estar en el pasado, a la vez se relacionan con el presente. Por ello, con esta serie Roda impone un desafío en el cual obliga a evocar estas huellas para entender una obra de arte contemporáneo. Así, pasado y presente se encuentran conectados de una manera singular, lo que lleva a indagar sobre nuestras conexiones con concepciones y costumbres cristianas de tiempos anteriores.

8 La búsqueda de estas huellas también hace que el trabajo de la investigación sea entendido como el rastreo de los recuerdos, vestigios y memorias que son evocados por el artista. En una de sus conferencias sobre Derrida, Yves Hersant (HERSANT, 2014) advierte sobre el hecho de que nosotros todavía acogimos los fantasmas de nuestra sociedad solamente con el objetivo de vituperarlos. Pero los fantasmas son huellas que sobreviven, pese a todo, y cabe al investigador enfrentarlas de la manera que corresponde.

9 Uno de los grandes investigadores que abordó estas huellas presentes en las artes fue Georges Didi-Huberman. Partiendo de los escritos de Sigmund Freud y de Aby Warburg, Didi-Huberman denomina estos recuerdos olvidados “síntomas-visuales', dado que el síntoma sería "la infernal escansión, el movimiento anadiomeno de lo visual en lo 
visible y de la presencia en la representación" (DIDI-HUBERMAN, 1990: 195). Así, para él, todo lo que describe una imagen es partido por un síntoma, y todo lo que le obsesiona es cruzado por un olvido (DIDI-HUBERMAN, 2005: 42). El principio del movimiento anadiomeno es crear una ruptura o una desfiguración en las imágenes a partir del momento en el cual él trae a la superficie estos olvidos, o estas huellas, antes que ellas emerjan de vuelta. Tener en cuenta los síntomas es rechazar cualquier síntesis simbólica o interpretación totalizante de la historia del arte, pues a través de estos síntomas es posible encontrar las infinitas grietas abiertas por los olvidos. Por lo tanto, para el autor, estar frente a una imagen es estar siempre ante un tiempo que nos excede (DIDI-HUBERMAN, 2011).

10 A partir de estas tres paradojas propuestas, se busca reflexionar sobre el problema de la transgresión y del erotismo en la obra de Roda. En cuanto a la transgresión, aquí ella no opone nada a nada, no rompe con un fundamento, ni derrumba una prohibición o quiebra una regla. En realidad, en la obra la transgresión debe ser entendida como un "gesto que concierne al límite", como diría Michel Foucault (FOUCAULT, 2012: 16), puesto que el objetivo del artista es jugar con los límites del bien y del mal, de lo sagrado y de lo profano, del lenguaje (verbal y visual) y de los tiempos.

11 Para eso, Roda utiliza la metáfora que, de por sí, es un juego de lenguaje transgresivo, pues viola el orden de la estructura del lenguaje y el límite del espacio significante (RICOEUR, 2006 : 168). Además, estos juegos de lenguaje producen lo que denominamos "movimientos de amor", término acuñado por Paul Ricoeur, y a la vez generan el erotismo de la obra en la danza sensual entre los amados.

12 Vale recordar que erotismo y religión siempre estuvieron juntos, pese al intento de algunos religiosos de separarlos a lo largo de la historia. En este sentido, las planchas de Roda no subvierten la lógica de la religión, sino comparten con ella el hecho de que son movidas por la transgresión. El mecanismo, según Georges Bataille, sería el siguiente :

Las transgresiones, aún multiplicadas, no pueden acabar con la prohibición, como si la prohibición fuera únicamente el medio de hacer caer una gloriosa maldición sobre lo rechazado por ella. Esta última frase contiene una verdad primera: la prohibición fundamentada en el pavor no nos propone solamente que la observemos. Nunca falta su contrapartida. Derribar una barrera es en sí mismo algo atractivo ; la acción prohibida toma un sentido que no tenía antes de que un terror, que nos aleja de ella, la envolviese en una aureola de gloria. (BATAILLE, 2009 : 52)

13 Para el autor, tanto lo sagrado como el sexo son envueltos por una aureola de gloria construida por las prohibiciones que los rodean. Gracias a estas prohibiciones, el impulso de transgredir la aureola para alcanzar el objeto prohibido es acompañado por los sentimientos de temblor y miedo. Por un lado, en la religión estos sentimientos introducen la confusión, sin la cual la religión es inconcebible (BATAILLE, 2009 : 74). Por otro, en el erotismo, su esencia se encuentra en la presencia de estos sentimientos y en la asociación inextricable del placer sexual con lo prohibido (BATAILLE, 2009 114).

14 Así, Bataille afirma que existen dos preceptos ineludibles en esta lógica. En primer lugar, estos sentimientos de miedo y temblor generan en un primer momento el deseo de transgredir lo prohibido. Sin embargo, la transgresión solo puede ser realizada, y el objeto prohibido alcanzado, cuando estos sentimientos son superados. En segundo lugar, no existe transgresión sin prohibición y viceversa. Por lo tanto, la transgresión solo es efectiva si es capaz de levantar las prohibiciones sin suprimirlas (BATAILLE, 2009 : 40). Teniendo en cuenta este último precepto, se podría concluir, como lo ha hecho Foucault, que la transgresión también es la afirmación de las prohibiciones, pues 
al mismo tiempo que se transgrede se afirma la existencia de la interdicción. Sin embargo, esta afirmación no tiene nada de positivo, pues lo que afirma es simplemente el hecho de que comparten una misma experiencia (FOUCAULT, 2012 : 20).

Las religiones, para Bataille, entran en este contexto con el objetivo de ordenar la transgresión. Sin embargo, mientras que en algunas religiones la transgresión no solo era permitida sino necesaria, en el cristianismo fue casi totalmente abolida. Así, las fiestas catárticas de las supuestas "religiones arcaicas", donde las transgresiones eran permitidas bajo algunas reglas, dio lugar a las misas y a las penitencias; en otras palabras, al espacio racionalizado, utilitario, moralista y autoritario de la "versión moderna" del cristianismo.

Pese a esto, Bataille cree que es posible rescatar el lado transgresivo del cristianismo, que todavía existe, bajo una de las formas más sublimes : las experiencias místicas. Para él, en el cristianismo "el éxtasis se funda en la superación del horror. El acuerdo con el exceso que se lleva por delante toda cosa es a veces más agudo en las religiones en las cuales el pavor y la náusea han roído más profundamente el corazón" (BATAILLE, 2009 : 74).

17 Al escribir sobre el misticismo, Per Buvik señala acertadamente que Bataille se revela mucho más religioso que ateo, pues lo que él busca con esta experiencia es la recuperación de una versión medieval del cristianismo que sea "mucho más centrada sobre lo sagrado que sobre la moral, privilegiando así la mística y el éxtasis" [Traducción de la autora] (BUVIK, 2010 : 10-11). Para que esto sea posible, todo el aparato dogmático del cristianismo se torna necesario con el solo objetivo de poder transgredirlo.

... a pesar de esta concesión al cristianismo, Bataille, aproximándose sensiblemente a la posición de Freud sobre el tema, critica el hecho de que para adaptarse a la civilización moderna el sistema de creencias cristianas creó prohibiciones absolutas, con el objetivo de disminuir la "dimensión transgresiva" de una forma originaria de religiosidad y, por consecuencia, de controlar sus aspectos más violentos: la muerte y la sexualidad. Precisamente estos dos últimos impases fundaron las propias raíces de la experiencia sensible, irracional y transgresiva que propone Bataille [Traducción de la autora] (DELLA CASA, $2014: \mathrm{s} / \mathrm{p}$ )

En definitiva, es preciso dejar en claro que aquí se discute no la obra de un Bataille blasfemo y ateo, como suele ser conocido, sino la de un autor que no pretende romper con el cristianismo. Al contrario, pretende revitalizarlo en su forma "más auténtica", como él mismo afirma ${ }^{4}$. Esta versión de Bataille es capaz de liberar la obra de Roda de sus interpretaciones freudianas, basadas en el arquetipo santo-penitente, hechas por críticos de arte que fueron bastante influenciados por el "psicoanálisis salvaje" que estaba en boga en los años 1970. Esto solo es posible porque, como se verá, existen muchos puntos en común entre las ideas del filósofo y la obra del artista. El principal es que los dos están en todo momento jugando con los límites de lo sagrado y del lenguaje.

19 La obra de Bataille, al igual que algunos textos de Ricoeur, de Freud, de Derrida y de Didi-Huberman, es de extrema importancia para entender la serie de grabados en cuestión. Así, el desafío propuesto es realizar algunas lecturas cruzadas que ayuden a reflexionar sobre esta obra, a partir de conceptos como el erotismo, la transgresión, el espectro y el síntoma visual. Para lograrlo, resulta necesario discutir sobre los juegos de lenguaje del título y los juegos visuales en los cuales las metáforas ${ }^{5}$, las yuxtaposiciones y las superposiciones son predominantes. 
20 A continuación, se segmenta la obra en diferentes partes para después proponer una interpretación. Siguiendo esta lógica, en el primer apartado se expone quiénes serían estas monjas que supuestamente estarían representadas. En el segundo, se presenta una breve reflexión sobre la idea de la muerte en el cristianismo para, en el tercer apartado, discutir sobre lo que sería el delirio según Freud, el cristianismo y Bataille. Una vez entendidos estos tres puntos, en el cuarto apartado se analizan las imágenes a partir de la idea de movimientos de amor, según Ricoeur, y de la idea de erotismo sagrado pensada por Bataille.

\section{Los espectros de las monjas muertas y sus nupcias místicas}

21 Según el artista, la obra es inspirada por algunos cuadros, sacados de un convento, que son retratos de monjas coronadas y muertas (RODA, 1988: s/p). Probablemente estas obras hacían parte del convento de la Concepción ${ }^{6}$, que fue declarado en 1582 el primer convento de clausura de Santa Fe de Bogotá. Estos retratos, hechos justo después de la muerte del individuo, eran comunes en los conventos latinoamericanos hasta el siglo XIX y provenían de una práctica artística denominada "memento mori", que significa "recuerda que vas a morir" (GUIOMAR, 1967). Con esta práctica, los cristianos tenían como objetivo recordar a los vivos la superficialidad de la vida relacionada al lujo y a las realizaciones terrestres, y hacerlos reflexionar sobre la muerte y la unión del espíritu con su Dios. La muerte era entonces entendida como la entrada al paraíso y la posibilidad de unirse con el Divino Esposo. Por eso llegaba a ser tan deseada.

Específicamente en cuanto a los retratos de las monjas coronadas, sus orígenes pueden ser encontrados en la tradición española de retratar monjas muertas, práctica que también ha tenido su desarrollo en Hispanoamérica. A esto se suma los retratos de monjas coronadas vivas, que surgieron en los virreinatos hispanoamericanos en el siglo XVI. Ambos retratos tuvieron su auge entre los siglos XVIII y XIX, inspirados en los retratos de Santa Rosa de Lima (1586-1617), difundidos por tierras americanas justo después de su beatificación en 1668 (SCOCCHERA, 2014 : 6).

Las monjas de Hispanoamérica, cuando era el caso, solían ser retratadas en las tres etapas de su coronación : en el día de su profesión, cuando se celebraban sus primeras bodas místicas con Cristo y su voto perpetuo de obediencia, pobreza y castidad; en la conmemoración de sus nupcias místicas de 25 y 50 años, que eran realizadas con el objetivo de reconocer la labor espiritual de las monjas; y justo después de su muerte, cuando el alma se separa del cuerpo para unirse en la eternidad con el Divino Esposo. Para llegar a ser coronada y devenir monja de una congregación, el camino era largo y consistía en diferentes etapas de formación que debían ser cumplidas. Las criollas, por ejemplo, tenían que vivir algunos años como novicias, probar que en su familia no había ni negros ni indios (MARTÍNEZ CUESTA, 1995 : 590-591), pagar una dote importante y, solo después, esperar por su profesión perpetua. Durante esta ceremonia, las monjas hacían sus votos, recibían su anillo matrimonial y, en la mayoría de los casos, recibían otro nombre. Así, celebraban no solo su matrimonio con Cristo, sino también su muerte social. Sin embargo, la consumación de las nupcias místicas, como se verá más adelante, acontecería solamente después de su muerte física (MURIEL, 1979). 
Pese al hecho de que los retratos de la última coronación se encuentran diseminados por todo el virreinato, estos encontraron su mayor expresión en Nueva Granada (MONTERO ALARCÓN, 2002). Las monjas solían ser representadas con su corona de rosas, una palma, una vela encendida, un Niño Dios, un anillo, un escudo y el velo. En la misma secuencia, según Adriana Almeida ${ }^{7}$, los significados de estos símbolos en la tradición católica son los siguientes:

1. La corona de rosas podría tener dos significados distintos: puede ser entendida como el signo de Cristo que recibe la monja durante la celebración de sus nupcias, o como el símbolo de la victoria, pues solo las monjas que tuvieron una vida ejemplar podrían ser coronadas en su muerte ; en estas pinturas, las rosas también podrían significar gracia y belleza ; dado que la rosa roja también podría ser símbolo del martirio, mientras la blanca evocaba pureza.

2. La palma, muchas veces remplazada por los ramilletes floridos en los retratos de las monjas, es la representación del martirio que se relaciona a la dura y sacrificada tarea de mantenerse casta.

3. La vela encendida, para los católicos, es un símbolo de Cristo, cuya cera es su carne, la mecha su alma y la luz de la llama, su divinidad.

4. El Niño Dios era una especie de muñeco que representaba a Jesús en su infancia y que tenían algunas monjas en sus celdas. Ellas lo cuidaban, le hacían nuevas vestimentas, etc., como si fuera su hijo. Así, Jesús niño y Jesús esposo criaban una gran paradoja en la vida de las monjas, pues las hacían ser madres y esposas a la vez.

5. El anillo, curiosamente poco representado en los retratos de las monjas coronadas, es un recordatorio de su matrimonio con Jesús.

6. El escudo era distintivo de las órdenes religiosas y pertenecía a los conventos.

7. El velo es el símbolo original y más antiguo de la consagración de las vírgenes. Sin embargo, en el virreinato fue tomando otras significaciones desde el momento en el cual las monjas pasaron a distinguirse por el color de sus velos. En muchos casos, las que portaban el velo negro eran las criollas, mientras quienes portaban el velo blanco eran las indias, mestizas, etc. Estos dos grupos poseían funciones distintas en el convento. En cuanto al convento de Bogotá, teniendo en cuenta que solo aceptaban "monjas de puro linaje", los colores servían para distinguir las novicias (velo blanco) de las que ya habían hecho sus votos perpetuos (velo negro) (VARGAS, 2010: 179).

Anónimo, Sor María Gertrudis Teresa de Santa Inés, aprox.1730

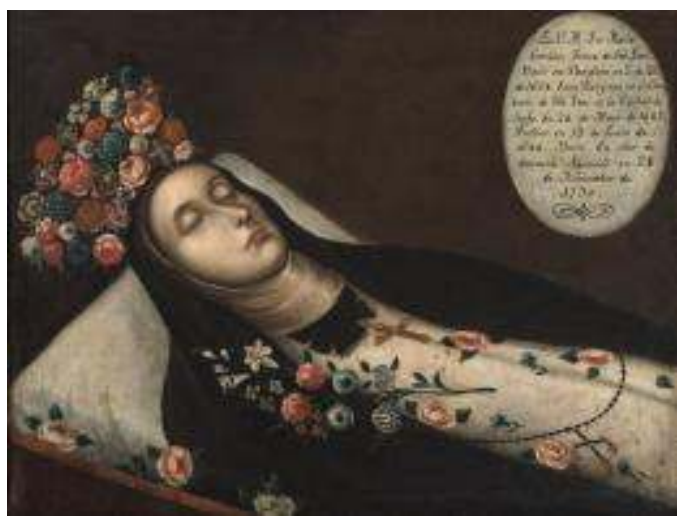

Óleo sobre tela, 59 × 73 cm, Bogotá, colección particular. Fuente : http://www.museocolonial.gov.co/ exposiciones/permanentes/Paginas/Sor-Mar\%C3\%ADa-Gertrudis-Teresa-de-Santa-Inés.aspx. Última consulta : 30/05/2016 
En esta imagen de Sor María Gertrudis Teresa de Santa Inés, se observa la presencia de algunos de los símbolos tratados arriba, como la corona de rosas, el ramillete de flores y el velo. También se ve una inscripción explicativa donde se señala la fecha de nacimiento, de profesión y de muerte. Su expresión facial, como la de la mayoría de estas monjas que fueron retratadas, demuestra una cierta austeridad acompañada por un cansancio y un sufrimiento contenidos. Los ojos están casi del todo cerrados, lo que hace confundir su instante de muerte con un instante de dormición. Además, el cartel informa que ella "murió en olor de eminente Santidad". Según la tradición católica, este olor puede ser emanado de cadáveres de personas que vivieron ejemplarmente y así pudieron alcanzar la santidad y la muerte ideal; esto es, la que llevaría a estas personas al encuentro con Dios y a la consumación de las bodas místicas.

Considerando toda esta carga social y política de los retratos de las monjas muertas, se puede afirmar que, además de retratos, eran "imágenes ejemplificantes". Una de sus funciones era retratar a una monja que tuvo una vida y una muerte ejemplar para que sus compañeras, o incluso las mujeres laicas, la tomaran como ejemplo de vida. Cada vez que se retrata un ejemplo, se lo actualiza en el espíritu de aquellas que lo deben seguir, como se verá más adelante.

Solo las monjas ejemplares podrían alcanzar la consumación de las nupcias místicas después de la muerte. ¿Cómo sería este encuentro ? Sobre este tema fueron escritos innúmeros textos considerados sagrados, donde los autores hacían analogías entre el matrimonio carnal y el matrimonio espiritual con el objetivo de entender cómo sería el encuentro místico. Para no confundir estos dos tipos de matrimonio, los intérpretes de estos textos intentaron de forma insistente realizar un análisis alegórico de estos escritos, construyendo redes semánticas capaces de reorientar los significados de las palabras hacia la esfera espiritual. El objetivo era alejar la relación entre Dios y sus fieles de su marco sexual y diferenciar, lo mejor posible, el amor carnal del amor divino. Las confusiones eran frecuentes $\mathrm{y}$, por este motivo, uno de los textos más polémicos de la Biblia, el "Cantar de los Cantares", fue considerado como de lectura restricta por muchos religiosos. Según Orígenes (185-254 d.C), uno de los principales padres de la Iglesia oriental, este texto solo podría ser comprendido por aquellos que hubiesen verdaderamente avanzado en el camino de la renuncia a los placeres carnales (RICOEUR, 2001 : 300).

Pese a todo este esfuerzo de "deserotización", a partir del siglo XX, como afirma Ricoeur, las interpretaciones naturalistas o eróticas -como el autor prefiere nombrarlas- del "Cantar de los Cantares" fueron las que prevalecieron (RICOEUR, 2001 ; 301). Los adeptos a esta nueva vertiente están de acuerdo en al menos un punto : en el hecho de que la mística y la espiritualidad esponsales se alimentan del deseo. De esta manera, Dios y sus fieles, especialmente los que se dedican a la vida monástica, fueron vistos como seres deseantes y deseados. En esta relación de amor, lo que restaba a los ascetas en la vida era la práctica del martirio, de las penitencias y flagelaciones, pues era la manera que encontraban para permanecer en plena identificación con el sufrimiento de Jesús mientras esperaban alguna señal divina (DELUMEAU, 1983). Estas señales podrían aparecer en forma de sueños, visiones, fantasías y, en sus versiones más intensas, a través de la transverberación y el éxtasis. Después de mucho esperar, estos deseos solo serían contemplados después de la muerte del individuo. 


\section{La transgresión de la muerte}

funciona como el motor de "todo deseo religioso, de toda catarsis ritual, de toda transformación y, por lo tanto, de toda figurabilidad. Era necesario morir para poder semejarse" [Traducción de la autora] (DIDI-HUBERMAN, 1990 : 268). En otras palabras, la muerte era una oportunidad para los fieles de volver a semejarse a su Dios, puesto que este privilegio, según la mitología cristiana, se acabó cuando Adán y Eva cometieron el pecado y fueron expulsados del paraíso. Sin embargo, volver a semejarse no era una oportunidad para todos, pues "al final de la historia, el Juicio Final discrimina definitivamente las almas que permanecieran diferentes a su Padre, y aquellas que ganaron otra vez la perfección de su semejanza" [Traducción de la autora] (DIDI-HUBERMAN, 1990 : 268). Visto de esta manera, la muerte no es nada más que un ritual de pasaje, dado que ella en sí misma no significa el fin, sino el inicio de una nueva relación del hombre con su Dios.

Aquí se encuentra la gran paradoja de la muerte en el arte cristiano: el deseo de transgredirla estuvo siempre acompañado con el deseo de imitarla. El objetivo era "identificarse con la muerte de Dios en el imitatio Christi, para poder creer que se está matando su propia muerte, siempre a la imagen de su Dios que resucita" [Traducción de la autora] (DIDI-HUBERMAN, 1990: 267). Así, la muerte en las pinturas cristianas siempre buscaba identificarse con la muerte de Jesús, visto como la víctima sacrificial que llegó para salvar a la humanidad de su pecado original. No obstante, la idea era que, si su muerte se semejara a la de Jesús, estos individuos también se semejarían a Él a la hora de la resurrección ${ }^{8}$.

$\mathrm{Al}$ analizar los escritos de San Bernardo y de Santa Teresa de Ávila, también se observa la presencia de este intento de matar la muerte en la medida que esta significaba simplemente la liberación del alma para ir al encuentro de Dios. Por esto, la muerte era muchas veces deseada y esperada fervientemente. En sus Sermones sobre el "Cantar de los Cantares", San Bernardo afirma :

En consecuencia, si para alguno de nosotros, como para el santo Profeta, lo bueno es estar junto a Dios; o más claramente, si alguien entre nosotros es un hombre de deseos, que llega al extremo de desear la muerte para estar con Cristo, y lo desea con tal vehemencia que le abrasa esa sed y lo piensa sin cesar, ese, sin duda, recibirá al Verbo como esposo en el momento de su visita; es decir, cuando se sienta abrazado interiormente como por los brazos de la sabiduría, y así se vea poseído por la dulzura del santo amor. (SC 32, 2) .

Después de haber descripto lo que es el sufrimiento del alma en busca de Dios, cuando esta todavía está aprisionada por el cuerpo, San Bernardo continúa :

Todo esto tiene que padecer la esposa hasta que, una vez abandonada la carga de este cuerpo pesado, vuele y sean las propias alas de sus deseos las que la lleven a recorrer las llanuras de la contemplación y con el espíritu totalmente libre siga al amado a donde quiera que vaya. (SC 32,2$)$. 
Para San Bernardo, la muerte era justamente el momento en el cual el devoto recibiría su "premio" por haber sido fiel a Dios durante toda su vida. Esta recompensa sería, más allá de la muerte, la vida eterna y la unión de su alma con Dios. De esta manera, podría afirmarse que esta tan deseada unión, así como las ansias de semejarse a Cristo, en realidad son dos lados de un mismo hecho, es decir, del deseo de transgredir la propia muerte. Así, los cristianos revelaron que no querían ser punidos por el pecado de Adán ${ }^{10}$, y los artistas que los representaban en el momento crucial de la muerte lo hacían de tal manera que esta pareciese tan digna como la que tuvo Jesús.

En las pinturas de las monjas muertas de siglos anteriores, así como en la versión contemporánea de estas monjas encontradas en los grabados de Roda, se observa el deseo de que estas muertes fuesen identificadas con el imitatio Mariae que, a su vez, sigue el mismo principio del imitatio Christi. Sobre la muerte (o dormición, término que aparece en muchos escritos hagiográficos) de la Virgen María y su resurrección (o Asunción), hay muchas versiones. La polémica está en si ella ascendió al cielo antes de haber muerto o tres días después de su muerte. Lo importante, en todo caso, es tener en cuenta que, según esta doctrina, María también burló la muerte y su alma fue directo al encuentro de Dios.

Según Ángel Peña Martín, este culto a la Asunción de la Virgen fue ampliamente difundido entre los conventos de la monarquía hispánica entre los siglos XVI y XVIII (PEÑA MARTÍN, apud SCOCCHERA, $2014: 4$ ). Con esta propagación del mito, también llegó a las Américas el deseo instaurado en las mujeres creyentes en semejarse a María, entendida como un exemplum de mujer, tanto en la vida cuanto en la muerte. Incluso mejor, habrían de semejarse en la vida para que pudiesen tener la gracia de semejarse a ella en la muerte y, en consecuencia, en la resurrección. Así, estas monjas llevaban, como la Virgen, una vida ejemplar ${ }^{11}$, y muchas entre ellas también se volvían exemplum antes mismo de sus muertes físicas.

Estos comportamientos, que revelan un profundo rechazo al cuerpo, pueden ser justificados por el hecho de que esta "vida" direccionada a Dios era una vida relativa, pues ya empezaba ella misma con la muerte. Como se ha visto, para vivir en la vida divina hay que morir para sí. Esta sería una muerte social en la cual el individuo abdica de su individualidad y de sus ambiciones terrenales (como el egoísmo, la vanidad, la ganancia, etc.) y carnales para dedicarse única y exclusivamente a los intereses de Dios. Según Bataille, esta muerte en la vida hace que los valores y los sentidos de la vida se transformen en su contrario (BATAILLE, 2009: 236). Así, se puede observar que la muerte para los ascetas posee en realidad dos etapas distintas e inseparables, pues es la primera muerte (que acontece en la mente) la que cambiará todo el sentido de la segunda muerte, que está relacionada con la muerte física.

Considerando todas estas tentativas cristianas de transgredir y subvertir la muerte, se podría afirmar que la obra de Roda sigue aproximadamente estos movimientos. Aquí, las monjas están muertas, pero lo que el autor narra es su visión sobre las creencias de las monjas con relación a lo que les sucedería después de sus muertes. Estas creencias muchas veces cobraban influjo en sus acciones y producían los sueños, visiones y fantasías que las acompañaban durante todas sus vidas. Estos, a su vez, no son más que diferentes grados de experiencias que son generadas por esta idea de muerte, como se verá en el siguiente apartado. 


\section{Los delirios de las monjas: entre Sigmund Freud, la tradición católica y Georges Bataille}

39 estaba muchas veces basada en el texto bíblico "Cantar de los Cantares". Por esto, los religiosos que narraban cómo sería esta vida post mortem y el encuentro del alma con Dios incluían en sus discursos metáforas, alegorías y juegos de lenguaje que rozaban de manera insistente el mundo de lo erótico. Aquí, el cuerpo y las sensaciones que generaban eran las principales fuentes de conocimiento sobre lo que podría ser este encuentro. La idea era que, como no había palabras para hablar de los placeres producidos por este momento místico, estos eran "traducidos" en lenguajes corporales para que pudiesen ser comprendidos. Estas "traducciones" generaron, como afirma Fernando Benítez, poesías eróticas de excelencia cuyos autores eran los santos españoles del siglo XVII (BENÍTEZ, 1989 : 135).

Sin embargo, el cuerpo que proporcionaba este entendimiento era el mismo que debía ser reprimido, olvidado y sacrificado, pues representaba la prisión del alma y la suciedad del mundo. En la confrontación entre placer, represión y necesidad de reemplazo del objeto deseado, se encuentra la formación del delirio. En este artículo se la entiende como una formación anímica cuyo origen se encuentra en el conflicto entre el deseo y las fuerzas que lo reprimen. Una de sus principales consecuencias es la generación de múltiples grados de deformación de la realidad, como afirma Freud en su libro "El delirio y los sueños en la Gradiva de W. Jensen" (FREUD, 2012, IX ; 23).

¿Acaso Roda clasifica estas creencias de las monjas, acompañadas por sus sueños y fantasías sobre sus encuentros con Dios, como deformaciones de la realidad? En principio, la respuesta es afirmativa, pues todas las tentativas de conceptualizar esta palabra llevan consigo el carácter de desvío o de confusión. Incluso, el significado etimológico de la palabra "delirar", tomada del latín "delirare", es "apartarse del surco" (COROMINAS et PASCUAL, 1984: 440), "descarrilar". Sin embargo, estas deformaciones o "descarrilamientos" están mucho más relacionados a la idea de transgresión "bataillana" que de enfermedad patológica, pues la experiencia del éxtasis, como se verá, es justamente este instante en el que la persona "sale de sí" y de todo su razonamiento cotidiano.

arriesgar que las imágenes de Roda son una tentativa de aproximación (con toda su carga interpretativa, por supuesto) a las imágenes producidas por los delirios, sueños y fantasías de estas monjas que fueron alimentadas por sus creencias sobre el encuentro con Dios. Para justificar esta afirmación, se hará una breve explicación de lo que sería el delirio para Freud. Antes, vale decir que fueron muchos los intelectuales que intentaron entender la vida de los Santos y sus experiencias místicas a la luz del psicoanálisis.

Gran parte de estas experiencias fueron consideradas como frutos de una patología por ejemplo, de la psicosis o de la histeria- y fueron pensadas a partir de conceptos como sublimación, regresión, delirio, etc. Sin embargo, el presente estudio, así como la obra del artista en cuestión, no está basado en las fuentes de la vida anímica de estas devotas. Por esto, la tentativa de identificar lo que sería el delirio de las monjas es limitada y, al mismo tiempo, abierta. Limitada porque el hecho de no contar con estas fuentes impide realizar un análisis y una descripción más profunda sobre lo que sería el 
delirio en este contexto. Abierta porque esta falta de fuentes anímicas es lo que permite, tanto al espectador como al artista, reflexionar y realizar asociaciones con el objetivo de expandir el horizonte a nuevas y múltiples interpretaciones. Estas asociaciones están basadas en los desarrollos de Freud, de la tradición católica y de Bataille. A continuación, se aborda, primero, la reflexión sobre el delirio en el psicoanálisis.

Para Freud, sueño, fantasía y delirio provienen de una misma fuente : lo reprimido.

el sueño es el delirio por así decir fisiológico del hombre normal. Lo reprimido, antes de adquirir suficiente fuerza para abrirse paso como delirio en la vida despierta, puede que alcance con facilidad su primer éxito, bajo las circunstancias más propicias del estado del dormir, en la forma de un sueño de prolongada eficacia. (FREUD, 2012, IX : 52)

Por su parte, considera a las fantasías del siguiente modo :

Son sustitutos y retoños de unos recuerdos reprimidos a los que cierta resistencia no permite llegar a la consciencia, no obstante lo cual consiguen devenir conscientes toda vez que arreglan cuentas con esta censura de la resistencia mediante unas alteraciones y desfiguraciones. Luego de consumado este compromiso, aquellos recuerdos se convierten en estas fantasías, sobre las cuales la persona consciente incurre en un malentendido, esto es, puede entenderlas en el sentido de la corriente psíquica dominante. (FREUD, 2012, IX : 49)

El sueño sería el lugar donde se presenta lo reprimido cuando las actividades anímicas están rebajadas, es decir, cuando se está dormido. A su vez, en la fantasía lo reprimido puede manifestarse en tres dimensiones distintas que se relacionan con sus tres modalidades: fantasías conscientes o sueños diurnos (las que son formadas en los estados de vigilia), fantasías inconscientes (las que surgen como estructuras subyacentes al contenido manifiesto del sueño), y fantasías originarias (las que son transmitidas filogenéticamente) (LAPLANCHE y PONTALIS, 2013 : 138-145). Por fin, el delirio sería cuando "unas fantasías han alcanzado el gobierno supremo, vale decir, han hallado creencia y cobrado influjo sobre la acción" (FREUD, 2012, IX : 38). Estas, a su vez, también pueden ser llamadas fantasías delirantes. Cabe recordar que en estas tres dimensiones lo reprimido aparece de forma desfigurada, pues esta es la única manera que el individuo encuentra para enfrentar el objeto reprimido.

47 Freud afirma que el desarrollo del delirio se inicia cuando "una impresión causal despierta las vivencias infantiles olvidadas, que presentan al menos los rastros de un tinte erótico" (FREUD, 2012, IX : 40) ${ }^{12}$. Cuando estas vivencias infantiles retornan a la consciencia, provocan una nueva batalla entre consciente e inconsciente. En medio de esta batalla, el delirio surge como una tentativa del individuo de reorganizarse y deshacer el trabajo hecho por la represión. En otras palabras, si al reprimir esta última provoca el desprendimiento de la libido en relación con el mundo exterior, el delirio llega para intentar restablecer este vínculo. Por ello, esta formación anímica es entendida por el autor como una tentativa de curación.

Una vez entendido que sueños, fantasías y delirios son grados distintos de una misma formación, vale recordar la diferencia entre el concepto de sueño en la tradición católica -es decir, la que aparece en la Biblia y en los escritos hagiográficos- y en el psicoanálisis. Si bien las características apuntadas aquí son generales, lo importante es entender los fundamentos básicos que dieron origen a las innúmeras reflexiones sobre los sueños surgidas en estas dos vertientes. 
49 Mientras que para Freud las variantes del sueño son las fantasías y los delirios, para el catolicismo son las visiones y el éxtasis. Mientras que para Freud estas "formaciones" son consecuencias de una actividad psíquica referente al inconsciente del individuo, para los católicos la raíz de los sueños es exterior al individuo :

... ella reside esencialmente en las fuerzas invisibles - positivas y negativas- que gobiernan el mundo y los hombres. Frente a ellas, el durmiente es pasivo, en beneficio de la intrusión de las imágenes venidas de afuera. Además, él que sueña no es el único concernido por su sueño. Su sueño dice respecto al grupo, a la sociedad entera. Él esclarece sobre el destino colectivo y no solamente el individual, sobre la hora de la muerte y la ida al más allá, sobre el futuro del rey y del país, sobre la legitimidad de una acción que tiene que ser puesta en práctica, sea una guerra o un peregrinaje. [Traducción de la autora] (SCHMITT, $2003: 554$ )

50 En este caso, el sueño, como las visiones y el éxtasis, es un canal directo de comunicación entre el devoto y Dios. Según Jacques Le Goff (1999 : 691), en los escritos de tradición católica la frontera entre sueños y visiones es ambigua. A veces se hace una diferenciación entre visión clara y sueño a interpretar; otras, entre "visio" y "somnium"; pero, en una gran parte de los casos, visiones y sueños se mezclan. En cuanto al éxtasis, este sería una forma suprema de sueño generada por un intenso contacto con Dios. Según Tertuliano, "el sueño, en realidad, contribuye al reposo del cuerpo ; el éxtasis, al contrario, invade el alma para arrancarla del reposo : es así que el sueño se mezcla ordinariamente al éxtasis" [Traducción de la autora] (TERTULIANO, apud LE GOFF, 1999 : 705).

Debido a su potencial, el sueño fue muchas veces asociado con la herejía. En otras situaciones, la Iglesia también intentó separar lo que serían los sueños verdaderos (de origen divino) de los sueños falsos (de origen diabólico). Por fin, durante mucho tiempo los clérigos intentaron definir quién tenía y quién no tenía el derecho de producir sueños verdaderos. Estos eran designados a los mártires y a ellos mismos, dado que el sueño masculino era en su mayoría más válido que el femenino. En cuanto a esto, JeanClaude Schmitt señala que los sueños y las visiones de las monjas eran definidos como legítimos solo después de haber pasado por el juicio de una autoridad masculina de la Iglesia. Como ejemplo, el autor recuerda la insistencia de Hildegarde de Bingen en comprobar que sus sueños o visiones espirituales no eran frutos de una locura o de alucinaciones causadas por la fiebre, mientras que el abad Rupert de Deutz, un hombre lleno de "auctoritas", hablaba naturalmente de sus sueños cuyo enlace místico estaba repleto de sutilezas eróticas (SCHMITT, $2003: 555)$.

52 Al intentar acercarse a los delirios de las monjas muertas y retratadas, Roda hace en realidad una superposición entre lo que sería la producción de imágenes de los sueños, fantasías, delirios, visiones y éxtasis, según la tradición católica y según la tradición psicoanalítica, que tiene su base en Freud. Como se verá a continuación, los delirios en la serie de grabados pueden ser entendidos como parte del éxtasis y las visiones, como fantasías ; mientras que los sueños también pueden ser entendidos como generados por un proceso psíquico interno o por un elemento externo. Por ahora, resulta necesario explorar un poco más la relación que hace Freud entre la religión y la represión de los instintos. Una relación que está íntimamente ligada con el imitatio Mariae y con el arquetipo santo-penitente.

53 Según Freud, gracias a los votos de castidad, condición necesaria para tornarse monja, se observa la represión de un instinto y la transferencia de un impulso hacia lo divino. Este proceso es constitutivo de lo que él denomina "arquetipo caso de represión en la 
vida del santo-penitente". Este arquetipo puede ser verificado en las biografías y escritos de los santos católicos y aparece en diversas obras de arte, como la de Felicién Rops. Para Freud, uno de los grandes éxitos de este artista fue lograr representar este arquetipo en la pintura "La Tentación de Santo Antonio" (1878).

Un monje asceta se ha refugiado - sin duda de las tentaciones del mundo- en la imagen del Redentor crucificado. $Y$ hete aquí que la cruz se esfuma como una sombra, y en su lugar, en sustitución de ella, se eleva radiante la imagen de una voluptuosa mujer desnuda en la misma postura de crucifixión. (FREUD, 2012, IX: 30).

54 En su lectura sobre la obra, Freud concluye que la religión, presentada a través de la imagen del redentor crucificado, fue el recurso utilizado por San Antonio para reprimir alguna pulsión erótica. No obstante, justo a través del recurso represor surgió el elemento reprimido que otrora fue "crucificado" por el santo. En este caso, la mujer ${ }^{13}$.

Ahora bien, las reflexiones que hacen los psicoanalistas parecen, a los ojos de Georges Bataille, demasiado ingenuas puesto que suelen pensar el problema "desde fuera". Así, Bataille propone analizar este amor divino de otra manera, es decir, no como una transferencia del amor carnal hacia lo sagrado. Para este autor, la efusión mística y la sexual, pese al hecho de que poseen sistemas similares y son dignas de comparación, son dos procesos distintos, puesto que en la primera estos movimientos son radicados en el ámbito interno de la consciencia y no dependen del juego real y voluntario de la materia. Sin embargo, el deseo sexual que otrora fue prohibido a los ascetas tiene un rol fundamental en la construcción del erotismo presente en la vida sagrada. ¿Cómo funciona esto ? Según Bataille, cuando el asceta decide "morir para sí" para poder vivir la vida sagrada, hace que determinados valores de la vida sean invertidos.

"En su deseo de morir para sí [el del asceta] se traduce su aspiración a la vida divina ; a partir de ahí empieza una mutación perpetua, donde cada elemento se transforma sin cesar en su contrario. La muerte, que el religioso ha querido, se transforma para él en la vida divina. Se opuso al orden genital que iba en el sentido de la vida, y vuelve a encontrar la seducción bajo un aspecto que ahora tiene el sentido de la muerte. Pero la maldición o la muerte, que la tentación de la sexualidad le propone, es también la muerte considerada desde el punto de vista de la vida divina buscada en la muerte de sí. Así la tentación tiene un doble valor de muerte" (BATAILLE, 2009 ; 236).

Siguiendo este raciocinio, si antes el sexo estaba relacionado con la vida, después pasa a estar relacionado con la tentación y la muerte. A partir de entonces, a través de la efusión sexual el religioso no puede perder su vida física, pero puede perder la vida divina a la que todos sus deseos son destinados. Si se tiene en cuenta que los deseos sexuales son una constante en la vida monástica - basta recordar los escritos de San Agustín o las tentaciones de San Antonio-, es posible afirmar que el religioso suele estar en contacto permanente con la tentación. Pero lo que le atrae no es exactamente lo genital, sino lo erótico generado por toda esta situación (BATAILLE, 2009 : 236).

Para Bataille, la tentación "es el deseo de desfallecer y de prodigar las reservas disponibles hasta el límite en que se pierda pie" (BATAILLE, 2009: 245). Sin embargo, contra ella actúa el deseo del asceta en salvar su alma. Estos dos movimientos contradictorios generan lo que el autor denomina "vértigo de la pérdida" (BATAILLE, 2009 : 236) y "erotismo culpable" (BATAILLE, 2009 : 245). Según Bataille, el deseo sexual no desaparece de la vida de los ascetas y tampoco es transferido a la esfera religiosa. Este, incluso, es parte del erotismo existente en la relación entre Dios y sus fieles. La 
otra parte de este erotismo está basada en las experiencias místicas y en el erotismo sagrado, lo que tiene que ver con el éxtasis, con la tentación, la transgresión y con todas las formas de trance, tal como se verá más adelante. Por ahora, basta esclarecer que para Bataille el misticismo y la sexualidad son similares, comparables, y uno puede ayudar en la comprensión del otro, pero son dos cosas distintas.

al ser análogas las intenciones y las imágenes claves en ambos campos, siempre cabe que un movimiento místico del pensamiento desencadene involuntariamente el mismo reflejo que una imagen erótica tiende a desencadenar. Si es así, debe de ser verdad la recíproca : los hindúes basan de hecho los ejercicios del tantrismo en la posibilidad de provocar una crisis por medio de una excitación sexual. (...) Así queda claro que entre la sensualidad y el misticismo, que obedecen a principios similares, siempre es posible la comunicación (BATAILLE, 2009 : 252-53). pues este autor no admite que a partir de una represión de los deseos del cuerpo hubo una transferencia hacia el amor divino. Así, por más que el arquetipo santo-penitente se muestre bastante atrayente para entender la serie de grabados - de hecho, fue bastante utilizado por críticos de arte para analizar la obra (COBO BORBA, apud NAVARRO, 2012 : 123-124 ; MEDINA, apud TRABA, $1977: 13$ )-, se debe considerar que el artista no tuvo acceso a la vida anímica de estas monjas y tampoco es posible lo que él entendía precisamente como delirio. El mismo autor de los grabados afirma lo siguiente :

... influenciados por Freud, nos parece lógico el simbolismo de lo erótico con referencia al misticismo, y quien mire superficialmente esta serie corre el riesgo de quedarse ahí. Pero conociendo los antecedentes de la poesía mística española, que me parece maravillosa, creo que hay que ser absolutamente serios al analizar estos factores, porque para los místicos el matrimonio con Cristo es algo que tiene un sentido muy profundo. (RODA 1988, s/p)

61 En este sentido, puede ser forzosa la interpretación de una obra a partir de este arquetipo. Sin embargo, esto no invalida las reflexiones realizadas sobre el delirio y los sueños en Freud y en la tradición católica. Al describir estos dos puntos de vista sobre las experiencias místicas, se ha mostrado cómo las categorías sueños, fantasías, visiones, éxtasis y delirios son deslizantes, es decir, cómo una puede transformarse de golpe en la otra. Todas ellas, a su vez, están relacionadas al desenlace final de la unión eterna. Por eso, muchas veces estas experiencias fueron consideradas como un anticipo de lo que sería este encuentro definitivo con Dios.

\section{Misticismo y erotismo: entre Paul Ricoeur y Georges Bataille}

Han sido varias las interpretaciones naturalistas (o eróticas) de la obra "Delirio de las monjas muertas", así como también las alegóricas. En este artículo, se elige la primera 
vertiente, pues se considera que lo erótico en las imágenes de Roda es el resultado no solo de los signos en sí mismos, sino del juego y de los movimientos que forman entre ellos. Tal interpretación no se contradice con la tradición católica, pues fueron innúmeros los devotos que escribieron textos que rozaban insistentemente el mundo de lo erótico.

En la obra en cuestión, así como en la Biblia, son abundantes los signos metafóricos. Aquí, estos símbolos no poseen significados intrínsecos. Por esto, solo pasan a tener sentido cuando son entendidos en su conjunto, es decir, en todos los grabados de la serie y en su interacción con cada elemento de un grabado en particular. A partir de esta interacción, se trabajará con la posibilidad de que un significante tenga múltiples significados a la vez. La idea es experimentar la dialéctica de Didi-Huberman, en la cual él afirma que es necesario "pensar la tesis con la antítesis, la arquitectura con sus fallas, la regla con su transgresión, el discurso con su lapsus, la función con su disfunción [...], o el tejido con sus rupturas" [Traducción de la autora] (DIDI-HUBERMAN, 1990 : 175). Así, siguiendo esta dialéctica, lo que se intenta en este artículo es entender la imagen y los deseos implícitos a través de sus rupturas, de sus grietas abiertas y de sus signos desfigurados. El objetivo es reflexionar sobre cómo están figurados los deseos, las culpas, los amores y las pulsiones reprimidas de estas monjas, a través de la óptica del artista.

Esta óptica, a su vez, está construida a partir de una herencia, de las huellas de un pasado que aparecen en la obra. En estas imágenes se observa la presencia de signos que fueron bastante utilizados en las pinturas del barroco americano, de referencias a pinturas clásicas europeas y de alusiones a textos sagrados o textos clásicos sobre el erotismo. El artista, frente a todas estas huellas, las transforma, les cambia los significados, las reordena. En resumen, las transgrede.

Vale recordar que esta dialéctica no permite construir una narrativa racional y lineal de las imágenes, y tampoco entre ellas. Así, las subdivisiones efectuadas a continuación no son más que tentativas de ordenar las conclusiones sobre el material analizado, teniendo en cuenta que el material en sí mismo no sigue ninguna lógica de ordenamiento. Además, vale aclarar que los elementos que componen estas subdivisiones no son estables y se entremezclan constantemente.

Por fin, el eje central para comprender el juego metafórico de la obra es el erotismo ${ }^{14}$, entendido a través de los movimientos de amor de Ricoeur y del erotismo sagrado de Bataille. Para Ricoeur, lo erótico en el "Cantar de los Cantares" no es necesariamente “... el eufemismo que mantiene la referencia sexual sin nombrarla directamente, sino más bien la inclusión del cuerpo mismo dentro del juego metafórico general del poema" (RICOEUR, 2001 : 283). A su vez, para Bataille el erotismo sagrado se encuentra, sobre todo, en las prohibiciones religiosas y sus relaciones con la transgresion.

\section{Los movimientos de amor y Paul Ricoeur}

67 Si se observa con atención, los grabados de la serie "El delirio de las monjas muertas" son formados a partir del movimiento de todos los elementos ahí presentes. Ellos respetan la lógica clásica de composición de una obra (división en planos, cortes horizontales, puntos de fuga, etc.), al mismo tiempo que forman lo que se denomina movimientos de amor. Estos, según la lectura de Ricoeur sobre el poema Cantar de los 
Cantares, pueden ser divididos en dos tipos : el movimiento entre vigilia y sueño y el movimiento en el espacio.

Según lo observado en este artículo, estos movimientos también están presentes en los grabados y tienen como soporte, por un lado, el espacio virtual dado por el negro que funciona como un "estuche oscuro", como afirma Marta Traba (TRABA, 1977 : 15); este espacio por sí mismo remite a la sensación de que las figuras no tienen un apoyo concreto y por esto están suspendidas en el aire, o en lo profundo de los pensamientos. Por otro lado, Navarro propone analizar este espacio a partir de la idea de espacio liso y estriado, acuñada por Gilles Deleuze y Félix Guattari. Para esta autora, los grabados son espacios lisos, continuos, donde se mueven los objetos (NAVARRO, 2012:120). Sin embargo, vale recordar que, como afirman Deleuze y Guattari, "el espacio liso no cesa de ser traducido, transvasado a un espacio estriado; y el espacio estriado es constantemente restituido, devuelto a un espacio liso" (DELEUZE y GUATTARI, 2002 : 485).

En la obra de Roda también se observa este vaivén entre lo liso y lo estriado ; es decir, la fluidez de los movimientos y de las formas siempre cae en la técnica tradicional del grabado y en las limitaciones de los objetos, mientras estos dos últimos son los que abren los caminos para la existencia de los primeros. Así, es posible afirmar que el espacio estriado de las planchas prepara la danza sensual entre los amantes y permite la existencia de todo nomadismo existente en la serie. De la misma manera, las líneas figurativas de las imágenes dan espacio a la desfiguración, para que esta pueda traer a la luz el movimiento anadiomeno de lo visual en lo visible y de la presencia en la representación, como diría Didi-Huberman.

Respecto a los movimientos de vigilia y de sueño, para Ricoeur, en el poema "Cantar de los Cantares" ellos tienen que ver con el "va y viene", jamás narrativo o lineal, entre el despertar (de la amada) ${ }^{15}$, la vigilia y el sueño, donde la vigilia pasa a ser fácilmente el comienzo de un sueño. Así, en el poema "estas alternancias entre sueño y vigilia, entre dormir y despertarse pertenecen a la misma dinámica de deseos entrelazados y a la interacción de distancias que se abren y cierran" (RICOEUR, 2001 : 282).

En los grabados de Roda, este vaivén nómada está relacionado con la formación delirante y con la concepción cristiana de sueño discutida anteriormente, en las cuales un estado psíquico (para los psicoanalistas) o un momento místico (para los cristianos) puede convertirse repentinamente en otro. En este sentido, el artista condensa los momentos místicos o psíquicos vividos por las monjas. Por esto, es difícil distinguir cuándo se refiere a los sueños, al éxtasis o a la unión mística.

En cuanto a los movimientos de distancia, Ricoeur encuentra en el "Cantar de los Cantares" al menos tres tipos de movimientos que componen la relación entre los dos amados : de aproximación ${ }^{16}$, de alejamiento ${ }^{17}$ y de supuesta consumación del amor ${ }^{18}$. Así, él afirma lo siguiente :

esta movilidad, que a veces desconcierta al querer seguirla, por sus cambios de tono, es la señal de un juego, el juego del deseo, o mejor el de dos deseos que se mezclan. El entramado de estos deseos está hecho de movimientos recíprocos que, partiendo de uno van al otro, y vuelven luego al punto de partida para irse otra vez hacia el otro (RICOEUR, $2001: 281$ ).

Estos deseos y los movimientos en el espacio que les da vida aparecen en la obra de Roda al menos de dos maneras:

\section{La aproximación y el alejamiento}


En los grabados la presencia de los cuerpos genera una gran parte del erotismo existente. Aquí los cuerpos son fragmentados, transfigurados y a veces ocultados. Son fracciones de cuerpos que participan del juego metafórico de la obra, que se mezclan con el paisaje y que desorientan al espectador. En un contacto pleno entre dos amados, sus cuerpos se confunden y, muchas veces, se funden.

Al mismo tiempo, también son objetos metonímicos en los que la parte puede evocar el todo. Por esto, en los grabados no hay la presencia de una figura directa que represente a Dios o a la monja por entero, pero sí varios signos o fragmentos corporales que les hacen mención o que les pertenecen. Estos signos son los que principalmente realizan el movimiento de alejamiento y aproximación en relación a los cuerpos.

En cuanto a los signos de alejamiento, se observan dos principales. El primero es la tijera de la Fig. 12 que se presenta como si fuera una extensión de los dedos de la mano que la sostiene. Aquí, el hilo cortado sale de la boca de la monja. ¿Será este el hilo de la vida que, al ser cortado, la lleva al encuentro con Dios ? ¿O será el hilo que la separa de su divinidad y le muestra su carácter humano ? El segundo signo es el falo masculino, símbolo más evidente y al mismo tiempo más banal del amor profano, que va en dirección opuesta al cuerpo de las monjas en las Figs. 5 y 3, es decir, no lo penetra.

En contraposición, hay otros signos fálicos que van en dirección a sus cuerpos, como las plumas (Figs., 7, 8 y 10), la luz (Figs. 2 y 3) y los dedos (Figs. 2, 8 y 9). Así, estos hacen que los deseos se unan nuevamente. Como se observa, estos signos son derivaciones del falo y cumplen más o menos la misma función : la de aproximación y alejamiento. Por lo tanto, estos signos están insertados en lo que aquí se denomina "red metafórica del falo". En algunas de estas imágenes el tinte erótico se encuentra a veces matizado y a veces bastante evidente, como en la Fig. 2 donde las plumas alcanzan los senos de la santa mientras los dedos los acarician, o en la Fig. 9, donde los dedos también acarician los labios de la monja.

\section{La Consumación}

El anónimo autor del "Cantar de los Cantares", o probablemente "autora", según Ricoeur, no describe ni muestra la posesión o la consumación del acto entre los amantes, pero sutilmente la evoca a partir de los movimientos. En los grabados de Roda, a su vez, el encuentro místico y la consumación de la boda son aludidos en toda la serie, pues la obra está basada en estos momentos de la experiencia de las monjas. Sin embargo, este encuentro no se da de una sola vez, sino paulatinamente, con sus idas y venidas, sus insinuaciones, caricias y romanticismo.

Esta unión está más explícita en las Figs. 2, 4 y 7. En la 2, los dos amantes se unen a través de las manos que están a la derecha de la imagen, donde la mano, cuyo brazo sale desde el cuerpo de la monja, parece llevar la otra mano que viene de arriba hacia su cuerpo. En la 4, son los dedos de los amantes los que se entrelazan. Aquí, la monja está representada con las flores de la corona usada durante las ceremonias místicas y, además, estas flores están acompañadas por otra rosa en forma de antorcha, cuyo pistilo está en la sombra y posee una forma fálica. ¿La rosa-antorcha, en este caso, sería una nueva versión de lo que significaba la vela y la rosa antiguamente en los retratos de las monjas muertas? Es decir, una mezcla entre el alma y el cuerpo de Jesús, por un lado, y la victoria, la pureza y el martirio de Cristo, por otro.

La Fig. 7 quizás sea la más enigmática de todas, pues la monja trae en sus entrañas la figura de una persona (¿el Niño Dios de los antiguos retratos de las monjas ?) y, además, 
posee un corazón en forma de rosa y con un pistilo fálico (¿una alusión al sagrado corazón de María ?), como en la Fig. 4. La unión se daría a través de los dedos que se confunden con las venas del cuerpo, o del cordón umbilical que une la madre a la criatura que está en sus entrañas. Esta es la única imagen que también hace referencia a la monja como madre, dado que en las otras ella aparece sobre todo como amante. Sin embargo, las formas fálicas no desaparecen de la figura, pues son ellas las que forman el Inmaculado corazón de María y las venas del cuerpo de la santa. Así, tienen el poder de tornar presente en la imagen no solo el erotismo que envuelve la relación entre Dios y sus devotos, sino también de mostrar la paradoja que existe en la construcción de la imagen de la Virgen madre y amante a la vez. Esta imagen está relacionada al gran deseo de estas monjas, e incluso de muchas otras mujeres devotas, de semejarse a la Virgen ${ }^{19}$.

Otra interpretación que podría darse a la Fig. 7, que de ninguna manera se contradice con la interpretación anterior, es que este ser que la monja porta en sus entrañas sería la presencia de lo que define la experiencia mística para Jacques Lacan. En su Seminario $\mathrm{XX}$, dedicado a este tema, él afirma que en la experiencia mística uno experimenta la sensación de que en su intimidad existe algo exterior a ella, lo que él define como "extimo". Esta sensación hace que se experimente una satisfacción irreconocible y casi indecible; por ello, en el discurso místico las ambigüedades y la presencia de una tentativa de descripción de lo que no se puede describir es recurrente ${ }^{20}$ (LACAN, 1975). Así, esta "criatura interna" que se encuentra en la Fig. 7 estaría directamente relacionada con este "otro" que pasa a hacer parte de la intimidad de las monjas y que, muchas veces, ejerce un poder muy fuerte y impositivo sobre sus cuerpos.

Los movimientos de amor en la obra de Roda, comparables a los movimientos del "Cantar de los Cantares", son los que dan vida a las imágenes, los que teatralizan este encuentro místico y demuestran a los mortales los placeres que puede llegar a tener un alma cautiva. Son ellos los que, incluso, generan una gran parte del erotismo que se encuentra alrededor del tema. La otra parte está relacionada con los espectros, es decir, con la propia lógica del erotismo presente en las religiones y en las innúmeras referencias a obras de arte y a escritos del pasado que fueron consagrados como eróticos.

\section{El erotismo sagrado de Georges Bataille}

83 Lo que está en juego en el erotismo sagrado, para Bataille, es siempre una disolución de las formas constituidas ${ }^{21}$. Tal disolución es la única capaz de hacer que el erotismo alcance su objetivo principal: la fusión y la consecuente disolución de los seres discontinuos.Además, en este tipo de erotismo el objeto posee dos particularidades importantes : la primera es el hecho de que no es físico ; la segunda es que, como dice el propio nombre, es sagrado. Para Georges Bataille, el fundamento para que un objeto sea sagrado es que él sea cercado por una interdicción, lo que lo hace igualmente participar de la siguiente lógica :

La prohibición, al señalar negativamente la cosa sagrada, no solamente tiene poder para producirnos - en el plano de la religión - un sentimiento de pavor y temblor. En el límite, ese sentimiento se transforma en devoción; se convierte en adoración. Los dioses, que encarnan lo sagrado, hacen temblar a quienes los veneran; pero no por ello dejan de venerarlos. Los hombres están sometidos a la vez a dos impulsos: uno de terror, que produce un movimiento de rechazo, y otro de atracción, que 
gobierna un respeto hecho de fascinación. La prohibición y la transgresión responden a esos dos movimientos contradictorios: la prohibición rechaza la transgresión, y la fascinación la introduce. Lo prohibido, el tabú, sólo se opone a lo divino en un sentido ; pero lo divino es el aspecto fascinante de lo prohibido : es la prohibición transfigurada. (BATAILLE, 2009 : 72)

Así, a partir del momento en que el religioso supera sus miedos y alcanza un cierto desapego respecto del mantenimiento de la vida, es capaz alcanzar el trance, o el sagrado. Fenómeno este en el cual sentimientos y atracciones opuestas - como el miedo y la fascinación, la obscenidad y el amor idílico, la delectación morosa y el apareamiento del zángano - se unifican y generan la liberación de movimientos de la vida que habitualmente están comprimidos, lo que provoca "el desbordamiento de un infinito gozo de ser" (BATAILLE, 2009 : 252). Este gozo, según G. Bataille, es el fruto de una transgresión "permitida", es decir, la que hace parte del juego sagrado descripto arriba y que no huye a la normalidad (BATAILLE, $2009 ; 269$ ).

los grabados de Roda, la presencia de estas experiencias mística es evidente en algunas imágenes (Figs. 5, 6, 11, 12). Aquí, las expresiónes de las monjas, las posiciones de los cuellos y los movimientos de aproximación y alejamiento se semejan al éxtasis de Santa Teresa, inmortalizado en la escultura de Bernini (1647-1651), y a las propias palabras de la Santa.

Quiso el Señor que viese aquí algunas veces esta visión : veía un ángel cabe mí hacia el lado izquierdo, en forma corporal, lo que no suelo ver sino por maravilla ; (...). Veíale en las manos un dardo de oro largo, y al fin del hierro me parecía tener un poco de fuego. Este me parecía meter por el corazón algunas veces y que me llegaba a las entrañas. Al sacarle, me parecía las llevaba consigo, y me dejaba toda abrasada en amor grande de Dios. Era tan grande el dolor, que me hacía dar aquellos quejidos, y tan excesiva la suavidad que me pone este grandísimo dolor, que no hay desear que se quite, ni se contenta el alma con menos que Dios. No es dolor corporal sino espiritual, aunque no deja de participar el cuerpo algo, y aun harto. (...) antes en comenzando esta pena de que ahora hablo, parece arrebata el Señor el alma y la pone en éxtasis, y así no hay lugar de tener pena ni de padecer, porque viene luego el gozar. (VIDA $29: 13-14)^{22}$.

Podríamos entonces hacer un paralelo entre este relato y las Figs. 5 y 6, en las cuales la presencia del éxtasis se pone más evidente. En la Fig. 6, estos movimientos aparecen de una manera muy intensa, pues el alma es extraída violentamente del cuerpo, lo que genera en la monja una especie de sufrimiento y goce a la vez. En cuanto a la Fig. 5, el falo no está penetrando el cuerpo de la monja que está dormida. De este modo, él actuaría, así como el objeto que penetra el cuello de la monja en la Fig. 6, como el dardo de oro que, al salir del cuerpo de Teresa de Avila, lleva consigo todas sus entrañas y la deja toda "abrasada de amor".

En la Fig. 12, la referencia al éxtasis o a la unión mística es más sutil y está relacionada a la posición del cuello y a la hora de la muerte, presente en el acto de cortar el hilo de la vida. A su vez, en la Fig. 11 está presente, sobre todo, el goce. En esta imagen la monja aparece, al contrario de las otras, con una sonrisa. Al lado de su rostro, encontramos una esfera partida por una línea vertical, signo que hace parte de la cadena metafórica de la esfera que sera analizada a continuación. Además, mientras se encuentra en esta composición la participación del cuerpo femenino, también se observa la presencia del alma que fue liberada de su "prisión" y ahora posee "alas para volar en dirección a su amado", como diría San Bernardo. Así, se concluye que los movimientos entre la 
sonrisa, el ojo y el ala sugieren una relación entre la satisfacción de los deseos del cuerpo y aquellos del espíritu.

Sin embargo, como se ha visto anteriormente, para Bataille el goce nunca es puro en la experiencia mística, pues como es fruto de una transgresión, está siempre acompañado por la idea de tentación y de pecado. Así, también se observa en los grabados este otro lado de la experiéncia mística, a través de los juegos metafóricos que incluyen las figuras del penacho, del jaguar y de las formas esféricas

En cuanto a las dos primeras figuras, penacho y jaguar, están relacionadas a una de las grandes prohibiciones que rodearon la vida de las monjas latinoamericanas por muchos años : la cultura del "otro", lo que podría ensuciar el camino sagrado elegido por ellas. Por más que la mayoría fuesen criollas y nacidas en las Américas, este "otro" eran sus propios conterráneos, es decir, los indígenas que no compartían la fe y los costumbres cristianos. Las monjas criollas de por si no podían tener sangre indígena. Además, eran educadas para no aceptar cualquier tipo de sincretismo cultural y religioso.

En este sentido, la Fig. 10 es la que más sintetiza estas prohibiciones. Aquí, la monja dormida es acariciada en la altura de los labios por una pena. En la cabeza están puestos un penacho a la izquierda y el velo a la derecha. Del otro lado de la imagen se observa una mano que sostiene un ojo $\mathrm{y}$, al mismo tiempo, genera una sombra con la forma de un jaguar. Justo los dos signos que representan las Américas, que serían el penacho y el jaguar, se encuentran en la oscuridad, mientras las luces destacan los otros elementos. El juego de sombras hace que estos signos aparezcan de manera disimulada en los grabados, como se estuviesen "por detrás" de los referentes principales. La oscuridad también muestra "el otro lado" del ser, que en este caso sería el lado más profano o más misterioso del mundo sagrado.

91 El penacho en las sociedades indígenas es símbolo de estatus, de protección y de coraje. Muchas veces es usado solamente por los caciques y durante las ceremonias religiosas. En la Fig. 10, él aparece no solo como la marca del mestizaje prohibido para estas monjas, sino también como signo de algo que las acompaña por toda la vida si tenemos en cuenta el pasado colonial americano, conocido por la conversión y la masacre realizados por la Iglesia con los pueblos indígenas.

92 A su vez, los jaguares aparecen en las Figs. 10 y 1 . En ambas están en segundo plano y son casi imperceptibles. En la Fig. 1, el animal está desfigurado y se encuentra detrás de la cabeza que es dibujada por una mano, mientras que en la Fig. 10 aparece como la sombra de la mano que sostiene el ojo. Estos animales son típicos de las Américas y son uno de los más presentes en las religiones indígenas. Además, muchas veces son usados por estas como tótem. De manera general, son vistos por las religiones indígenas como animales misteriosos y como símbolos de los poderes ocultos e incomprensibles (GARZA, 1987), de ahí surge la facilidad que los cristianos tuvieron en asociarlo al demonio $^{23}$.

93 En este sentido, se puede deducir que los jaguares y el penacho son sinécdoques visuales, en las cuales la parte representa el todo. Aquí, los jaguares o los dioses indígenas, así como los penachos o los propios indígenas, fueron pueblos masacrados culturalmente y físicamente por los cristianos, pero no desaparecieron y por esto están presentes en los grabados como sombras y como la otra parte de los signos principales.

94 Los jaguares aparecen dos veces y están acompañados por la figura de un ojo. Aquí, el ojo no es más que parte de un juego metafórico constituido por figuras esféricas que se 
desplazan y se transforman en senos (Fig. 8), testículos (Figs. 3,5), huevos (Fig. 11) y rosas (Fig. 4). En esta cadena metafórica no existe un término generador y todos los signos poseen igual importancia. Además, como en el juego metafórico de las formas fálicas, la cadena esférica también es parte del erotismo entre los amantes. Por ende, se denomina esta cadena de "falismo redondo", término que Roland Barthes utilizó para analizar la metáfora del ojo en el libro "Historia del ojo" de Georges Bataille (BATAILLE, 2003).

Es interesante observar que las formas esféricas pertenecen tanto al mundo femenino como al masculino, siendo todos ellos relacionados a la fertilidad. Los senos y las rosas son femeninos, siendo que el primero es sobre todo sensual (en oposición al seno maternal), puesto que es acariciado por los dedos; y el segundo es el símbolo de las nupcias místicas, de la victoria, de la gracia, la belleza y el martirio, es decir, todo lo que acompañaba la monja en su vida religiosa. Los testículos, masculinos, en su acepción corriente también son llamados huevos. A su vez los ojos, tanto femeninos cuanto masculinos, son los que definen las reglas de este juego entre las formas presentes en las imágenes.

Ellos pueden ser asociados al pecado en estos grabados a partir de dos perspectivas. En la primera, este sería la puerta de entrada para las tentaciones y los deseos superfluos. San Mateo, por ejemplo, afirma : "Ahora bien, si ese ojo derecho tuyo te está haciendo tropezar, arráncalo y échalo de ti" (Mateo 5 :28-29). En la segunda, ellos serían los propios ojos de Dios, los que "observan los caminos del hombre, y Él ve todos sus pasos." (Job 34, 21). Es decir, los ojos omnipresentes que vigilan la vida de los penitentes y que registran cada paso que dan hacia la tentación.

\section{Conclusión}

Los signos elegidos por Roda y sus cadenas de asociaciones poseen una multiplicidad de significados que no permiten cerrar una única interpretación a la obra. Por ello, fue necesario invocar sus innúmeras facetas, sus juegos de lenguaje y sus referenciales históricos, aquí considerados como espectros de la imagen. Del mismo modo, fue necesario desmembrar la obra en todas sus dimensiones y en diferentes etapas en busca de los síntomas visuales, de sus rupturas y de los caminos abiertos a la interpretación.

"El delirio de las monjas muertas" es un título que condensa múltiples sentidos. Incluso, se podrían proponer otros títulos para la obra que no estarían en desacuerdo con el título original. Por ejemplo, "El delirio de las monjas sobre el post mortem", "El delirio en vida que tuvieron las monjas que fueron retratadas después de su muerte", y así sucesivamente. Sin dudas, estos títulos serían menos poéticos y menos complejos que el original.

El juego metafórico del título también puede ser encontrado en las imágenes. Aquí, este se constituye a partir de los movimientos en el espacio, de la interacción entre las formas y de las conexiones que se pueden trazar entre estos signos y las referencias exteriores a la obra. Además, este juego metafórico permite que los tiempos se superpongan, mientras los objetos se funden, se reemplazan, se yuxtaponen y generan la ambigüedad y polisemia de los signos.

100 En este contexto, se observa que en las imágenes las categorías de sueños, fantasías, delirios, visiones y muerte se mezclan, pues nunca es muy claro si el autor se refiere a 
alguna de ellas o al momento de la unión eterna. Así, no sólo los tiempos históricos están yuxtapuestos en la obra a través de los espectros, sino también los tiempos individuales de las monjas. Ellas llevaban una vida en la que su principal preocupación era tener una "buena muerte" y en la que la unión eterna era vivida y sentida de a poco, como en las coronaciones realizadas en vida, o en las señales que tenían de haber sido elegidas. Tales señales aparecían en los sueños, delirios, fantasías, etc. Por ende, instante de muerte e instantes de vida se confundían. Además, la propia noción de delirio trae consigo la existencia de una confusión entre pasado y presente, como si fuera "una forma de anacronismo, [en la que] ciertos restos del pasado sobreviven y se reorganizan" (NAVARRO, $2012: 118)$.

Todos estos movimientos están en la esencia de la relación entre las monjas y su divinidad. Ellos traducen el mutuo deseo de poseer, de ser poseído y evocan la danza sensual entre los amados. Asimismo, forman el conjunto de herramientas elegidas por el artista para transgredir, es decir, para jugar con los límites de los tiempos, de las formas, de lo sagrado y de lo profano. Finalmente, revelan los espectros presentes en la obra, que la hace dialogar con el pasado, que la fracciona y la desfigura, para darle nuevos sentidos.

Roda logra, a partir de los gestos construidos siempre al borde de los límites, tornar presente en su obra todo el movimiento erótico existente en las experiencias místicas. Su gesto artístico y poético hace recordar las palabras de Michel Foucault sobre el cristianismo y la sexualidad:

Jamás la sexualidad tuvo un sentido más inmediatamente natural y jamás conoció, sin dudas, un gran 'éxito de expresión' que en el mundo cristiano de los cuerpos reprimidos y del pecado. Lo demuestran toda una mística, toda una espiritualidad que no podían absolutamente separar las formas continuas del deseo, de la embriaguez, de la penetración, del éxtasis y de la efusión que desvanece; todos estos movimientos se los sentía transcurrir sin interrupción ni límite, hasta el corazón de un amor divino donde eran, al mismo tiempo, la última erupción y la fuente para el regreso. [Traducción de la autora] (FOUCAULT, 2012:7).

En los grabados, nada es separable y nada es discontinuo. Los diferentes modos de experiencia mística se funden, mientras las formas de los objetos se van juntando y deslizando una hacia la otra. Por ejemplo, el falo masculino se mezcla con la experiencia mística y se va transformando en diferentes símbolos fálicos relacionados o no con el mundo sagrado; el jaguar, a su vez, se muestra como la otra faz del Dios cristiano ; mientras el ojo hace que tanto el pecado como la interdicción se tornen presentes en la imagen. Mediante estas transformaciones, Roda juega con las fronteras al desplazarlas y transgredirlas en todo momento. No obstante, al mismo tiempo que las desplaza, las afirma, lo que genera todo el erotismo presente en la obra y en la experiencia mística. 


\section{BIBLIOGRAFÍA}

BATAILLE Georges, El verdadero barba azul. La tragédia de Gilles de Rais, Barcelona, Tusquets Editores, 1972.

BATAILLE Georges, História do Olho, São Paulo, Cosac\&Naif, 2003.

BATAILlE Georges, El erotismo, Buenos Aires, Tusquets Editores, 2009.

BENÍTEZ Fernando, Los demonios en el convento. Sexo y religión en la Nueva España, México DF, Biblioteca Era, 1989.

BUVIK Per, L'identité des Contraires. Sur Georges Bataille et le Christianisme, Paris, Éd. du Sandre, 2010.

CASTRO VARGAS Hernando, «Jerarquías sociales y relaciones políticas : el convento de la

Concepción de Bogotá y la ejecución de censos (1739-1810) », in Revista Republicana, no 8, enerojunio, 2010, pp. 177-190.

CHEVALIER Jean y GHREERBRANT Alain, Dicionário de símbolos, Rio de Janeiro, José Olympio Editora, 2001.

сово воRBA Juan G., "Los grabados de Roda ”, in Colombia. Alcántara, Caballero, Roda. XII Bienal de Sao Paulo, Bogotá, Instituto Colombiano de Cultura, 1973.

COROMINAS Joan y PASCUAL Jose A., Diccionario crítico etimológico castellano e hispánico, Madrid, Editorial Gredos, 1984.

DeLeUZe Gilles y GUATTARI Félix, Mil Mesetas, capitalismo y esquizofrenia, Valencia, Pre-textos, 2002.

DELla CASA Martina ; “ “J'étais chrétien” : Bataille \& le christianisme”, in Acta fabula, enero 2014. http://www.fabula.org/acta/document8365.php. Consultado en 30/03/2016.

DELUMEAU Jean, Le péché et la peur. La culpabilisation en Occident (XIII-XVIII siècles). Paris, Fayard, 1983.

DERRIDA Jacques, Espectros de Marx, Valladolid, Editorial Trotta, 1998.

DIDI-HUBERMAN Georges, Devant l'image : question posée aux fins d'une histoire de l'art, 1 vol. Collection Critique, Paris, Éd. de Minuit, 1990.

DIDI-HUBERMAN Georges, Venus Rajada, Madrid, Editorial Losada, 2005.

DIDI-HUBERMAN Georges, Ante el tiempo, Historia del arte y anacronismo de las imágenes, Buenos Aires, Adriana Hidalgo, 2011.

FOUCAULT Michel, Préface à la transgression : hommage à Georges Bataille, Fécamp, Lignes, 2012.

FREUD Sigmund, Actes obsédants et exercices religieux, 1907. http://www.uqac.uquebec.ca/zone30/ Classiques_des_sciences_sociales/index.html. Consultado en 30/03/2016.

FREUD Sigmund, "El delirio y los sueños en la "Gradiva" de Jensen", in Obras completas : El delirio y los sueños en la "Gradiva” "de W. Jensen y otras obras (1906-1908), vol. IX ; Buenos Aires, Amorrortu Editores, 2012

GARZA de la Mercedes, “Jaguar y Nahual en el mundo Maya”, in Studia Humanitatis, México DF, FF y L de la UNAM, 1987. 
GUILHEM Olivier, Tezcatlipoca : Burlas y Metamorfosis de un Dios Azteca, México DF, Fondo de Cultura Económica, 2005.

GUIOMAR Michel, Principes d'une esthétique de la mort : les modes de présences, les présences immédiates, le seuil de l'au-delà, Paris, José Corti, 1967.

HERSANT Yves, "Derrida et les spectres”, in Derrida a sa place/ Derrida à sa place, Paris, EHESS, 2014. https://www.youtube.com/watch ?v =PV1u2nh10wk. Consultado en 25/03/2016.

HOYOS RESTREPO Andrés, “Entrevista a J. A. Roda por Andrés Hoyos”, in Roda, Bogotá, Davivienda, Ed. Galería El Museo, 2001a. http://www.juanantonioroda.com/pdf/entrevista.pdf. Consultado en 20/03/2016.

HOYOS RESTREPO Andrés, "Roda : entre la transparencia y la cultura ", in Roda, Bogotá, Davivienda, Galería El Museo, 2001b. http://www.juanantonioroda.com/pdf/andres_hoyos.pdf. Consultado en 20/03/2016.

JEsus Santa Teresa de, Libro de la vida, Madrid - Barcelona, Real Academia Española y Galazia Gutenberg, 2014.

LACAN Jacques, Le Séminaire XX, Encore, Paris, Seuil, 1975.

LAPLANCHE Jean, y PONTALIS Jean-Bertrand, “Fantasía ”, in. Diccionário de psicoanálisis, Buenos Aires, Paidós, 2013.

LE GOFF Jacques, "Le Christianisme et les rêves IIe-VIIe siècle", in Première publication in Colloque I sogni nel Medioevo, Lessico Intellectuale Europeo, Rome, 1983-1985. In Un autre Moyen Âge, Paris, Gallimard, 1999.

MARTíNEZ CUESTA Angel, “Las monjas en la América colonial 1530-1824”, in Thesauru, Boletín del instituto Caro y Cuervo, 1995.

MEDINA Álvaro, "El delirio de las monjas muertas", in Procesos del arte. Bogotá, Instituto Colombiano de Cultura, 1978.

MIKLOS Aline, "O interdito, a transgressão religiosa e a desobediência do corpo feminino na arte contemporânea e latino-americana", in Artelogie, no 6 (Junio), 2014. http://cral.in2p3.fr/ artelogie/spip.php?article324. Consultado en 30/03/2016.

MONTERO ALARCón Alma, Monjas coronadas en América Latina. Profesión y muerte en los conventos femeninos del siglo XVIII, México DF, UNAM, 2002.

MURIEL Josefina, Monjas coronadas, Mexico DF, Artes de México, 1979.

NAVARRo Adriana G., “ La continuidad en el delirio de las monjas muertas ", 9, 7, 2012. http:// revistas.udistrital.edu.co/ojs/index.php/c14/article/view/3975. Consultado en 15/03/2016.

RICOEUR Paul, “ La metáfora nupcial ”, in Pensar la biblia, estudios exegéticos y hermenéuticos, Barcelona, Herder, 2001, p. 275-309.

RICOEUR Paul, “ O processo metafórico ”, in A hermenêutica bíblica, São Paulo, Edições Loyola, 2006. RODA J. A., “Roda habla”, in Juan Antonio Roda. Grabados 1971-1985, Catálogo de exposición, Bogotá, Museo de Arte Universidad Nacional, 1988.

SAN BERNARDO, «El cantar de los cantares », in Obras completas de San Bernardo. vol. V, Madrid, Biblioteca de autores cristianos, 2014.

scHMITT Jean-Claude, "Récits et images de rêves au moyen âge", in Ethnologie française, avril 2003. 
SCOCCHERA Vanina, "Imágenes, lecturas y prácticas barrocas del buen morir : los tránsitos de la Virgen y San José en el monasterio de San José de Córdoba del Tucumán (Segunda mitad siglo XVIII)", in ASRI, octubre 2014. http://asri.eumed.net/7/virgen.pdf. Consultado en 10/03/2016. TOLEDO DE ALMEIDA Adriana, “Monjas Coronadas 2.0 Un tema del barroco hispanoamericano retomado por artistas contemporáneos", in Trabajo de Integración Final de la Licenciatura en Arte, Buenos Aires, Universidad de Palermo, 2013.

TRABA Marta, Los grabados de Roda, Bogotá, Museo de Arte Moderno, 1977.

TURINA Isacco, "Vers un catholicisme "exemplaire?", in Archives de sciences sociales des religions, mars 2006. https://assr.revues.org/3352 Consultado en 20/03/2016

WEBER MaX, Sociologie des religions, Paris, Gallimard, 1996.

\section{NOTAS}

1. Juan Antonio Roda hizo sus estudios en artes en la Escuela Massana de Barcelona. En 1955 se muda a Bogotá con su familia. En este país trabajó como profesor de dibujo en la Facultad de Arquitectura de la Universidad Nacional de Colombia, como director de la Facultad de Bellas Artes de la Universidad de los Andes y posteriormente como cónsul general de Colombia en España. Fue un artista de renombre en Colombia y maestro de otros artistas destacados como Beatriz González y Luis Caballero. Fuente: http://www.juanantonioroda.com/pdf/ cronologia.pdf, acceso 16 de junio de 2015.

2. Según Adriana Navarro, "la obra fue premiada en diversos eventos, como el XXIV Salón Nacional de Artistas (1973), la III Bienal de Puerto Rico (1974) y la I Bienal Americana de grabado, en Maracaibo, Venezuela (1977)" (NAVARRO 2012, 117). Todas las imágenes de la serie deben ser consultadas en la página web del artista: http://www.juanantonioroda.com. Ellas se presentan en el texto de acuerdo con su numeración en la página.

3. En sus escritos observamos una generalización inmensa cuando habla del paganismo o de las "religiones primitivas" o "arcaicas", lo que nos hace concluir que al hablar del "otro", Bataille en realidad habla de su propia cultura y nada más que esto.

4. Todavía sobre este tema, en el libro El verdadero barba azul, Bataille escribe sobre la transgresión y lo que denomina "la verdadera esencia del cristianismo" : "Ese desorden puede coexistir con el cristianismo más auténtico, siempre dispuesto a perdonar el crimen, aun el más atroz, aun el de Gilles de Rais. Tal vez, en el fondo, aquél exija el crimen, exija el horror : en cierto sentido, los necesita para poder perdonarlos. Así es, pienso, cómo debe entenderse la exclamación de San Agustín: Félix culpa! ¡Dichosa falta!, que alcanza todo su sentido ante el crimen inexpiable. El cristianismo consiente una humanidad cargada de ese exceso delirante, que sólo el propio cristianismo ha permitido soportar." (BATAILLE, 1972 : 36)

5. Marta Traba rechaza la utilización del termino "metáforas" y lo remplaza por "simbolizaciones", que son "modos operativos de concretar ideas, de manera que su sentido se nos declare sin reticencias." (TRABA, 1977 : 13-14). Para ella, no hay ninguna metáfora cuando se representan símbolos fálicos, es decir, no se permite una doble lectura. Sin embargo, en este artículo el termino "metáfora" es el más apropiado, pues por más que hayan falos, lo que define la metáfora son los juegos entre los signos presentes en la obra.

6. Adriana Navarro afirma que no se puede precisar exactamente de donde son estos retratos. No obstante, según lo que pudo averiguar, ella también cree que son del Convento de la Concepción (NAVARRO, 2012 : 117). 
7. Adriana Toledo de Almeida hizo un excelente análisis y resumen de la iconografía de las monjas coronadas en el barroco hispanoamericano, trabajo que nos sirvió de base para entender este tema. (TOLEDO DE ALMEIDA, 2013).

8. En la Biblia, una de las historias más emblemáticas sobre este tema es la resurrección de Lázaro de Betania dónde Jesús, además de probar la omnipotencia de Dios, alimenta la esperanza de los individuos en conquistar una vida eterna en su compañía. En el Evangelio según San Juan, cuando Marta, la hermana de Lázaro, le dijo a Jesús que si él hubiese estado, su hermano no habría muerto, Jesús le contestó : “ ‘Tu hermano resucitará'. Marta le respondió : ‘Sé que resucitará en la resurrección del último día'. Jesús le dijo : 'Yo soy la Resurrección y la Vida. El que cree en mí, aunque muera, vivirá ; y todo el que vive y cree en mí, no morirá jamás. ¿Crees esto ?’” (Juan 11, 21-26).

9. Preferimos hacer las citas de textos religiosos de la forma tradicional y todas las citas de San Bernardo fueron extraídas de la edición que citamos en la bibliografía.

10. Pues la muerte, en la mitología cristiana, es el castigo de Dios para el pecado de Adán. Según la Biblia, 'Así pues, por medio de un solo hombre entró el pecado en el mundo, y con el pecado la muerte, y la muerte pasó a todos porque todos pecaron.' (Romanos 5,12). En cuanto a la voluntad de transgredir la muerte, ella aparece en el pasaje siguiente: 'El pago que da el pecado es la muerte; pero el don que da Dios es vida eterna en unión con Cristo Jesús, nuestro Señor.' (Romanos $6: 23$ ).

11. Según Max Weber, en el mundo religioso existen dos tipos de profecía : (1) la ejemplar, que tiene como modelo "una vida dedicada a la salvación, una vida en regla general consagrada a la contemplación y al éxtasis apático" ; (2) la ética, o de misión, que "en nombre de un Dios, dirige al mundo exigencias provenidas naturalmente de la ética, y con frecuencia de la ascesis activa" (WEBER, 1996: 355).. Sin embargo, Isacco Turina defiende que estas dos categorías no son inmóviles, pues en una misma religión y hasta en un mismo asceta se pueden encontrar estas dos modalidades de prácticas la fe (TURINA, 2006). En este estudio, se considera que estas monjas llevaban una vida más ejemplar que ética por el hecho de que, la mayor parte del tiempo estaban clausuradas en los monasterios cuidando de sus propias salvaciones.

12. En el romance Gradiva (1903), de Wilhelm Jensen, el arqueólogo alemán Hanold se enamora de una mujer retratada en un bajo-relieve romano, lo que le hace crear en su mente algunas fantasías sobre cómo fue la vida de esta persona, dónde vivía, qué hacia, cómo caminaba etc. Estas fantasías se tornaron tan intensas que él tuvo la idea de ir en búsqueda de más informaciones sobre la mujer que, según sus sueños, venía de las ruinas de Pompeya. Al llegar en las ruinas, él conoce una mujer que supuestamente sería Gradiva, su amada. Sin embargo al hablarle, la mujer se da cuenta de lo que está pasando y le dice al arqueólogo que ella no era Gradiva, sino su amiga de infancia que, de un instante a otro, en el pasado él empezó a ignorarla. Lo que Freud quiere demostrar con esta novela de W. Jensen es que Hanold tuvo un amor reprimido en la infancia que fue encendido nuevamente por algún detalle del bajo-relieve. (FREUD, 1907)

13. Freud, en otros estudios posteriores como en su libro Observaciones psicoanalíticas sobre un caso de paranoia, dónde analiza el caso de Schreber, abandona un poco esta idea en la cual el objeto reprimido vuelve a través el aparato utilizado para la represión. Sin embargo, no la deslegitima.

14. Como se ha explicado, las interpretaciones eróticas de las escrituras y pinturas sagradas han tomado una gran dimensión en la actualidad. Sin embargo, para no caer en una lectura superficial de estas obras, muchos de sus intérpretes hicieron una separación entre lo sexual y lo erótico. El primero - lo sexual- sería, grosso modo, todo lo que hace mención directa a la actividad sexual relacionada con la reproducción. El segundo -lo erótico- sería todo lo que surge alrededor del primero, pero de manera independiente.

15. El las palabras de Paul Ricoeur, estos movimientos entre vigilia y sueño pueden ser identificados en varias partes del poema : “cuatro veces leemos : 'Hijas de Jerusalén, yo os conjuro 
por las gacelas y las ciervas de los campos : no despertéis ni desveléis a mi amada hasta que ella quisiere' $(2,7 ; 3,5 ; 5,8 ; 8,4)$. Y el despertar en 8,5 ('Te desperté bajo el manzano, donde te concibió tu madre, donde la que te alumbró te había concebido') no expresa propiamente una conclusión narrativa, por cuanto, como queda dicho, el despertar de 8,5 y el sello de 8,6 pertenecen a una misma economía de deseos mutuamente aceptados y reconocidos y, en este sentido, cumplidos. De modo parecido, los estados de vigilia - 'Mi amado es para mi y yo soy para él ; él apacienta el rebaño entre los lirios' $(2,16)$ - pasan a ser fácilmente comienzo del sueño : ‘en mi lecho, en la noche, buscaba yo al amado de mi alma' $(3,1)$, si es que no se convierten a las claras en un sueño entre 3, 2 y 5,1, como algunos comentaristas, como Daniel Lys, por ejemplo, han sugerido." (RICOEUR, 2001 : 282)

16. Paul Ricoeur ordena estos pasajes de la manera siguiente : "Apenas ha exclamado la amada en el prólogo ‘¡bésame con los besos de tu boca!', añade ‘¡llévame en pos de ti, corramos juntos !'. Hay luego la evocación de un andar vagabundo 'tras la grey de tus zagales'. Y un poco más adelante, dice ella : 'Me introdujo en la bodega, su enseña sobre mí es el amor' (...)” (RICOEUR, $2001: 283$ )

17. Estos pasajes son ordenados de la manera siguiente por el autor : "El amado llama a la puerta para entrar. Alcanza a entrar por la puerta entreabierta, pero entonces 'abrí a mi amado ; mas mi amado se había ido ya, había pasado'. Y el coro, un poco después, se mofa : ¿Adónde fue tu amado, la hermosa entre mujeres ?' ¿A que parte se tornó, que contigo lo busquemos?' (...)" (RICOEUR, $2001: 281$ )

18. “' 'Su izquierda por apoyo a mi cabeza ; con su diestra me abraza' (2,6 y 8,2). Y de nuevo : 'Mi amado es para mi y yo soy para él ; él apacienta el rebaño entre los lirios' $(2,16 ; 6,3)$. El amor carnal quizá se consuma en 5,1 o 6, 3, pero no se dice esto de un modo descriptivo. Más bien se canta" (RICOEUR, 2001 : 281).

19. La autora hace una discusión sobre este tema en el texto "O interdito, a transgressão religiosa e a desobediência do corpo feminino na arte contemporânea e latinoamericana" (MIKLOS, 2014).

20. Sobre la obra El éxtasis de Santa Teresa de Bernini (1647-51), Lacan afirma : "Basta ir a Roma para ver la estatua de Bernini para entender rápidamente que ella goza, de esto no hay dudas. ¿Pero de qué goza ella ? Es evidente que el testimonio esencial de los místicos es decir que ellos experimentan, pero sobre eso no saben nada" (LACAN, 1975)

21. Estas formas constituidas serían las formas "de vida social, regular, que fundamentan el orden discontinuo de las individualidades que somos”. (BATAILLE, 2009 : 23)

22. Todas las citas de Santa Teresa fueron hechas según la manera clásica de citar textos religiosos y fueron extraídas del libro JESUS (JESUS, 2014).

23. Para este asunto, ver (GUILHEM, 2005) y (CHEVALIER y GHREERBRANT, 2001). Nos gustaría agradecer inmensamente a Elena Mazzetto y Mariza Bortoli que nos ayudó a desvendar el tema.

\section{RESÚMENES}

Este artículo analiza la obra "El delirio de las monjas muertas" (1972-74), de Juan Antonio Roda (Valencia 1921 - Bogotá 2003), constituida por una serie de 12 grabados en aguafuerte, aguatinta y punta seca. A partir de conceptos como erotismo, transgresión, espectro y síntoma visual se indaga sobre el juego de lenguaje presente en el título y los juegos visuales en los cuales predominan las metáforas, las yuxtaposiciones y las superposiciones. Todos estos movimientos son centrales en la obra en cuestión y en la visión del artista sobre la relación entre las monjas y 
su divinidad. Ellos traducen el mutuo deseo de poseer, de ser poseído y evocan la danza sensual entre los amados. Asimismo, forman el conjunto de herramientas elegidas por el artista para transgredir, es decir, para jugar con los límites de los tiempos, de las formas, de lo sagrado y de lo profano. Así, este artículo pretende contribuir, en particular, a la comprensión de esta obra que ha sido debatida entre los críticos de arte, y, en general, al estudio de la relación entre el arte contemporáneo y el cristianismo.

Cet article analise l'oeuvre Le délire des religieuses mortes (1972-74) de Juan Antonio Roda (Valence 1921 - Bogotá 2003) et constituée par une série de 12 gravures à l'eau-forte, aquatinte et pointe sèche. À partir des concepts comme l'érotisme, la transgression, le spectre et le symptôme visuel, l'oeuvre sera interrogée d'après le jeu de langage présent dans le titre et les jeux visuels dans lesquels prédominent les métaphores, les juxtapositions et les superpositions. Tous ces mouvements sont centraux dans l'œuvre en question et dans la vision de l'artiste sur la relation entre les religieuses et sa divinité. Ce sont eux qui traduisent le mutuel désir de posséder, d'être possédé et le rapport qu'évoque la danse sensuelle entre les êtres aimés. Ce sont eux aussi qui forment l'ensemble des outils choisis par l'artiste pour transgresser, autrement dit, pour jouer avec les limites des temps, des formes, du sacré et du profane. Ce sont eux, enfin, qui révèlent les spectres présents dans l'œuvre, qui la font dialoguer avec le passé, qui la fractionnent et la défigurent pour lui donner de nouveaux sens. Ainsi, cet article essaie d'être une nouvelle contribution à la compréhension de cette œuvre - encore très débattue chez les critiques d'art et à l'étude de la relation entre l'art contemporain et le christianisme.

\section{ÍNDICE}

Palabras claves: grabado, latinoamericano, Roda (Juan Antonio), erotismo, arte y cristianismo, transgresión, monjas muertas, Colombia

Mots-clés: gravure, latino-américaine, Roda (Juan Antonio), érotisme, art et christianisme, transgression, religieuses mortes, Colombie

\section{AUTOR}

ALINE MIKLOS

EHESS/USP

alinemo[at]ehess.fr 